$\mathrm{A} \int_{\text {ass }} \underset{0976-272 \times \mathrm{x}}{\mathrm{H}}$

Article history :

Received : 18.09.2014

Accepted : 17.11.2014
Members of the Research Forum

Associated Authors:

${ }^{1}$ Department of Vegetable Science,

College of Horticulture, Halladkari

Farm, BIDAR (KARNATAKA) INDIA
Author for correspondence : S.J. IMAMSAHEB

Department of Vegetable Science,

College of Horticulture, Halladkari

Farm, BIDAR (KARNATAKA) INDIA

Email : imamjath@gmail.com
THE ASIAN JOURNAL OF HORTICULTURE

Volume 9 | Issue 2 |Dec., 2014 |484-491

Visit us -www.researchjournal.co.in

\title{
Impact of drip irrigation and fertigation on growth, yield, quality and economic returns in different vegetable crops
}

\section{S.J. IMAMSAHEB, C.N. HANCHINMANI ${ }^{1}$ AND K. RAVINAIK ${ }^{1}$}

ABSTRACT : The shrinking land, man ratio, water, increasing fertilizer prices, haunting energy crisis, wide spread population and fast degradation of natural resources further emphasise the need for improved water and fertilizer use efficiency. Drip fertigation optimize the use of water and fertilizer enabling to harness high crop yield, simultaneously ensuring a healthy soil and environment. The drip fertigation technology encompasses the application of solid and liquid mineral fertilizers through drip irrigation system thus supplying a nutrient containing irrigation water to crops. A study was conducted with drip irrigation in crop geometry for chilly, bhendi and capsicum crops during Kharif and Rabi season. The pooled data revealed that the highest yield was obtained in treatments with $1.5 \mathrm{~m}$ drip lateral spacing with plant spacing of $20 \times 72 \mathrm{~cm}$ for chilly and $2.5 \mathrm{~m}$ drip lateral spacing with a plant spacing of $20 \times 72 \mathrm{~cm}$ for bhendi which is higher by 55 per cent over control (Anonymous, 1995). Drip irrigation scheduling for brinjal, okra, tomato and cabbage and fertigation for bitter gourd with irrigation scheduled at 100, 80 and 60 per cent ET in main plots and irrigation intervals (daily, 1 and 2 days) in sub-plots showed that the yield of brinjal / okra was maximum at 80 per cent ET (Anonymous, 2004).

KEY WORDS : Drip irrigation, Fertigation, High value vegetables

HOW TO CITE THIS ARTICLE : Imamsaheb, S.J., Hanchinmani, C.N. and Ravinaik, K. (2014). Impact of drip irrigation and fertigation on growth, yield, quality and economic returns in different vegetable crops. Asian J. Hort., 9(2) : 484491. 